Original Research

\title{
A Qualitative Inquiry into The Adherence of Adults Type 2 Diabetes Mellitus with Dietary Programs
}

\author{
Kusnanto Kusnanto', Elfa Lailatul Izza ${ }^{2}$, Tri Johan Agus Yuswanto ${ }^{3}$, Hidayat Arifin² \\ ${ }^{1}$ Faculty of Nursing, Universitas Airlangga, Surabaya, East Java, Indonesia \\ ${ }^{1}$ Master of Nursing Study Program, Faculty of Nursing, Universitas Airlangga, Surabaya, East Java, Indonesia \\ 2 Poltekkes Kemenkes Malang, Malang, East Java, Indonesia
}

\section{ABSTRACT}

Introduction: Diabetes mellitus (DM) is a chronic disease with the characteristic of treatment complexity. The toughest challenge for DM patients is dietary adherence. On the other hand, the socio-culture is one of the factors that influences dietary adherence. The aim of this study was to examine the dietary adherence of adults with type 2 Diabetes mellitus (T2DM), particularly to dietary programs.

Methods: This study used a qualitative case study design with a positivist approach. The total participants consisted of 14 T2DM patients obtained through snowball sampling. The research phenomenon was the adherence of adults with type 2 Diabetes mellitus to dietary programs. The data collection was conducted through in-depth interviews with question guidelines analyzed using qualitative thematic analysis.

Results: This study obtained five themes regarding the dietary adherence of T2DM patients such as activity, motivation, intention, behavior, and the benefits of dietary adherence. The focus points were activity, motivation, and the intention to comply with the dietary recommendations, including reducing the fatty and fried foods consumed. The patients who felt the benefits of complying with the dietary program found following the dietary adherence to be easier.

Conclusion: Activity, motivation, intention, behavior and the benefits of the dietary adherence program all make it easier for the patient to comply with their diet. This result suggests that health workers should provide education to the patients on the importance, benefits and the way to comply with the T2DM dietary program.
\end{abstract}

\section{ARTICLE HISTORY}

Received: Dec 04, 2019

Accepted: Dec 11, 2019

\section{KEYWORDS}

adherence; behavior; diet; type 2 diabetes mellitus

\section{CONTACT}

Kusnanto

$\triangle$ kusnanto@fkp.unair.ac.id $\equiv$ Faculty of Nursing, Universitas Airlangga, Surabaya, East Java, Indonesia

Cite this as: Kusnanto, K., Izza, E. L., Yuswanto, T. J. A., \& Arifin, H. (2019). A Qualitative Inquiry into The Adherence of Adults Type 2 Diabetes Mellitus with Dietary Programs. Jurnal Ners, 14(2), 118-123. doi:http://dx.doi.org/10.20473/jn.v14i2.16417

\section{INTRODUCTION}

Diabetes mellitus (DM) is a health problem with the characteristic of hyperglycemia due to abnormal insulin secretion, insulin action or both. DM symptoms include polyuria, polydipsia, polyphagia, weight loss and blurred vision (ADA, 2017).The most common problem in T2DM is dietary non-adherence. One of the causal factors of this is socio-cultural, which drives the T2DM patients to not comply with the dietary recommendations (Basu \& Garg, 2017). Whether the patients comply or not depends on the intention of the person (Ajzen, 2005).

The incidence of T2DM in Indonesia has been rising every year. The data from the Baseline Health Research of Indonesia showed that T2DM patients aged $\geq 15$ years in 2013 had an incident rate of $6.9 \%$. This increased in 2018 to become $8.5 \%$. The prevalence was higher in women at $12.7 \%$ than in men at $9 \%$. The T2DM patients who did not take medicine made up 11\% (National Institute of Health Research and Development Indonesia, 2018). The data from the Public Health Center in Sidoarjo showed that the doctors had diagnosed 66,077 DM patients. From the 10 T2DM patients in Porong and Krembung Public Health Center, $70 \%$ of patients feel that it is difficult to comply with the suggested diet and $50 \%$ feel bored with the DM treatment.

The research conducted by (Storz \& Iraci, 2019) showed that patients who adhere to a diet for a short time can reduce their blood sugar concentration and increase their insulin sensitivity. Dietary adherence is 
highly effective when it comes to achieving better glycemic control in patients with type 2 diabetes. Adherence is supported by the environment and their family (Hilliard, McQuaid, Nabors, \& Hood, 2014). Strengthening the resilience of dietary adherence in the T2DM patients will provide enthusiasm and a better ability to treat themselves. This is in addition to improved self-esteem and behavior (De Souza Ribeiro et al., 2017)

The T2DM patients' dietary adherence can reduce the incidence of hyperglycemic crisis (PERKENI, 2015). The success of dietary adherence depends on the compliant behavior and intentions of the patients - compliance consists of close and open submissive behavior. Close compliant behavior is a stimulus that has not been clearly seen that is still limited to the form that the knowledge, attitude, perceptions and feelings takes. Open submissive behavior is a reaction to the stimulus in a way of practice that is visible (Notoatmodjo, 2007). Intention can be explained as motivational factors and they have a strong impact on behavior change. The firm intention of T2DM patients will increase their compliance in terms of carrying out dietary management properly (Pinidiyapathirage, Jayasuriya, Cheung, \& Schwarzer, 2018). Based on the description above, this study aims to examine the dietary adherence of adults with type 2 Diabetes mellitus (T2DM) on dietary programs.

\section{MATERIALS AND METHODS}

This study was a qualitative case study design used to inquire into the adherence of adults with type 2 diabetes mellitus to dietary programs with a positivist approach. The aim of a positivist approach is to explore a good story or experience from a participant related to their adherence to dietary programs. A case studies is a form of investigation and exploration that looks into a case in-depth and in detail. It allows the researchers to get a complete and detailed picture of the phenomenon that is to be studied. It involves the understanding of a person's events and activities (L Mccaslin \& Scott, 2003). The following steps are a part of case studies in order to ensure the best possible outcome: 1) information organization, 2) reading all of the information and coding, 3) writing a detailed description of the case and its context, 4) interpreting and developing generalizations naturally from the cases and 5) presentation in narrative form (Vanwynsberghe, 2007).

The participants of this study were 14 T2DM patients obtained through the snowball sampling technique. The inclusion criteria were 1) T2DM patients from the Public Health Center in Sidoarjo, East Java Province, 2) good dietary adherence according to dietary adherence screening and 3) not a pregnant woman. The exclusion criteria were 1) resident citizens from the Public Health Center in Sidoarjo, East Java Province and 2) not communicating verbally well.
The researchers themselves are the data collection tools and thus they cannot be represented or delegated. The data collection tools consisted of voice recorders, stationery, field notes and the indepth interview guidelines. The interview questions included behavioral attitude, subjective norm, perceived behavioral control, intention, and adherence behavior. The interview data was analyzed using qualitative thematic analysis by searching for any themes that emerge. This becomes important when looking into the description of a phenomenon or case. The stages of thematic analysis include: 1) developing manual code, 2) conducting reliability tests on the code, 3) summarizing the data and identifying the initial themes, 4) applying templates to the codes and supplementary codes, 5) linking the codes and identifying themes, and 6) strengthening and validating the theme (Fereday \& Muir-Cochrane, 2006).

The study was conducted in three Public Health Centers in Sidoarjo, East Java Province for two months, January 2019 - February 2019, with a high prevalence of good dietary adherence based on the successful achievement of the Public Health Centerran programs. The participants determined the location of the interview at the time of the informed consent contract. This study was registered to research ethics board of the Health Research Ethics Commission of the Faculty of Nursing, Universitas Airlangga, letter-number: No.1194-KEPK published on 3rd November 2018.

\section{RESULTS}

The participants in this study consisted of 14 people consisted of 1 male and 13 females aged between 45 85 years old. The most common education level of the participants was that of primary school. All of the participants were married. Most of the participants did not work. One participant (P12) dropped out because he didn't complete the interview stages. A total of five themes emerged from the results of the in-depth interviews concerning the dietary adherence of the T2DM patients such as activity, motivation, intention, behavior, and the benefits of doing dietary adherence. The characteristics of the participants have been summarized in Table 1.

\section{Theme 1: Activity}

Activities which increase dietary adherence include physical exercise (P10, P14), controlling their routine in the health care centre (P02, P15), reducing their sugar consumption (P01, P04) and praying to God (P06).

“...If I want my body to feel good, I do exercises like jumping in the field after cooking..." (P10)

"...I prefer walking around in the field while looking at green scenery. I feel better..." (P14) "...If I feel sick, I go to the health care centre to control it. Yesterday I felt unwell. Unfortunately, my uric acid was high..." (P02) 
Table 1. Characteristic of Respondents

\begin{tabular}{|c|c|c|c|c|c|}
\hline Code & Gender & $\begin{array}{c}\text { Age } \\
\text { (years old) }\end{array}$ & Marital Status & Work & Education \\
\hline P01 & Female & 53 & Married & Does not work & Junior high school \\
\hline P02 & Male & 68 & Married & Does not work & Junior high school \\
\hline P03 & Female & 70 & Married & Does not work & Primary school \\
\hline P04 & Female & 69 & Married & Does not work & Primary school \\
\hline P05 & Female & 73 & Married & Does not work & Junior high school \\
\hline P06 & Female & 85 & Married & Seller & Primary school \\
\hline P07 & Female & 45 & Married & Seller & Junior high school \\
\hline P08 & Female & 60 & Married & Does not work & Junior high school \\
\hline P09 & Female & 66 & Married & Does not work & Primary school \\
\hline $\mathrm{P} 10$ & Female & 65 & Married & Does not work & Primary school \\
\hline P11 & Female & 75 & Married & Does not work & Primary school \\
\hline P12 & \multicolumn{5}{|c|}{ Drop out } \\
\hline $\mathrm{P} 13$ & Female & 60 & Married & Does not work & Primary school \\
\hline P14 & Female & 57 & Married & Does not work & Primary school \\
\hline P15 & Female & 51 & Married & Does not work & Primary school \\
\hline
\end{tabular}

${ }^{*} P=$ Participants

“...I want to feel healthy, so I routinely control it in the health care centre..." (P15)

"... I used to drink less sugar milk. Now I have a little sugar on my meal..." (P01)

"... No, I do not eat sweet food. Fatty food also. I reduce the amount of sugar..." (P04)

"... I sincerely undergo this sickness. I prayed to

God to give me a healthy and long life..." (P06)

\section{Theme 2: Motivation}

This theme explained that the participant get their motivation from social support, including from the health workers (P03), other T2DM sufferers (P05) and their family (P06).

"...I get motivated to adhere to the diet from the doctor. The doctor said that I have to control my diet and he suggested for me to eat or take a meal once every three hours..." (P03)

“... T2DM patients who I am acquainted with always remind me about dietary adherence and they invite me to the DM association so then I can get support and more information..." (P05)

“...My wife reminds me about reducing my rice consumption, especially hot rice. If the rice is cold, then I can eat little more..." (P06)

\section{Theme 3: Intention}

This theme explained that the participants' intention rises after getting education from the health care provider (P01). The participants maintain adherence through considering the amount, type and time of the food consumption (P05).

"...After being educated by a health care provider, I have the intention to consider what I eat..." (P01)

"...For example, if I have eaten and someone offers me food, I reject it wisely..." (P05)

\section{Theme 4: Behavior}

This theme explained the dietary adherence behavior done by the participants. The dietary adherence behavior considers the amount, type and time of the food (P03, P15), the reduction of their sugar consumption (P06) and reducing the amount of fried food (P13).

"...I consider the amount of rice like $8-10$ spoons. I only eat rice three times a day in the morning, noon, and evening. Snacking is only at 3 PM..." (P03)

“...I eat every 3 hours and start at 7 AM. It consists of three-times eating eight spoons of rice and three times snacking. I avoid eating fried food ..." (P15)

"...I reduce my sugar consumption. I do not eat sweet fruits like yam..." (P06)

"...I avoid eating fried food and fatty chicken meat..." (P13)

\section{Theme 5: Benefit}

This theme explained the benefit of dietary adherence. The participant felt that dietary therapy could support their medical treatment (P01) and that accurate dietary therapy can reduce the signs and symptoms of sickness (P03, P05, P14).

"...I only consume medicine, but I think that it does not heal my sickness well. I combine medication and diet and hope that it can help prevent wounds..." (P01)

"...I do not comply with the diet. I feel sick like I have headache, plus tingling and pain. I comply with the diet only so then my glucose is stable and I do not feel sick anymore..." (P03)

"...My vision is a blur when my glucose is high. My vision is brighter when my glucose level is stable. My glucose level is stable when I comply with the dietary adherence..." (P05)

"...When I comply with dietary adherence, the pain and frequency of my urination decreases, my body is fit, and the tingling disappears..." (P14) 


\section{DISCUSSION}

The first theme revealed that physical exercise, controlling their routine in the health care centre, reducing the sugar consumption and praying to God emerged as activities that influence dietary adherence. (ADA, 2017) advises for people with DM to exercise at a medium to high intensity for at least 150 minutes per week. They should exercise for 15 minutes every two days and then the duration is increased slowly to at least 150 minutes per week according to the recommended amount (Colberg et al., 2016). Exercise not only reduces the blood sugar levels but it also lowers the blood pressure, reducing the levels of low-density lipids, increasing their energy, and reducing stress (Restuning, 2015). DM patients have to routinely undergo control visits to the doctor or Public Health Center every month. The time of control depends on the patient's condition. The worse their condition, the more often they have a control visit to the doctor or the health care provider. The provider will assist in their DM management through education, dietary therapy, exercise, and pharmacology therapy (Poretsky, 2017). DM patient need drugs and DM management to control their blood glucose level. Belief in God and in the power of prayer, as well as in religious instructions, is obtained in conditions of difficulty. This is proven to decrease the incidence of depression (Doolittle \& Farrell, 2004). The spiritual aspect has a significant influence on changes in patient behavior and motivation. The emotional stability resulting from good spiritual integrity not only affects the achievement of positive behavior but it also contributes to physical health (Friedman, 2018).

The second theme revealed that the participants get a variety of support which includes support from their family, from fellow DM sufferers, and from the health workers. The family factor has an important role in supporting diabetes management (Delamater, 2006). For patients with chronic conditions such as diabetes, social support has been shown to provide positive outcomes in relation to glycemic control, adherence to care, and improvements in their emotional status. Patients who have good family support will experience a comfortable feeling that can increase their motivation to comply with the dietary recommendations (Ilmah \& Rochmah, 2015). Social support from fellow DM sufferers has the same effect, or it was found to be better than support from their wives or friends who did not have diabetes (Van Dam et al., 2005). Interactions between the health workers and patients will lead to an understanding of the importance of treatment. Health workers give full attention to the patients, even though the consultation time is concise (Niven, 2002). Time is not a determinant of good quality interactions between the patients and health care workers. Friendliness, attention and the empathy of officers will provide a feeling of security and inner security (Moehyi, 1992). Communication is very important in the context of providing nutrition education to the patients, in their willingness to provide explanations and in offering alternatives which will help them to fulfill their patient's needs (Wahyuningsih, 2009).

The third theme revealed that participant's intention in relation to dietary adherence is to comply with the amount, types and timing of the food recommendations. The various intentions possessed by the participants are a way to increase the persistence in dietary adherence. Humans are unique individuals; the intention of each individual is varied. Different desires called intentions represent the functions of two basic determinants, namely individual attitudes towards a behavior (a personal aspect) and the individual perceptions of the social environment (Ajzen, 2005). Practice or behavior according to the Theory of Planned Behavior (TPB) is influenced by intention, while intention is influenced by subjective attitudes and norms (Sommer, 2011).

The fourth theme revealed that the participants were just trying to keep to the dietary adherence in the beginning and they whole-heartedly complied with the suggested guidelines. The results of this study also support the Skinner theory in that behavior is a person's response to a stimulus or object. Responding depends on the characteristics and other factors of the individual (Gordan \& Amutan, 2014). The acceptance of new behavior must be based on knowledge so then the behavior is long-lasting. The change or adoption of new behavior follows the following stages through the process of change: knowledge (attitude), attitude (attitude) and action (practice) (Notoatmodjo, 2003). Individuals begin with trial and error until they really want to apply it forever. According to (Green \& Kreuter, 1991), behavior is determined by three factors: predisposing factors (knowledge, attitudes, values and beliefs), enabling factors (facilities and infrastructure / facilities for the formation of healthy behavior) and reinforcing factors (family support/friend /figures/groups, health workers, health insurance and decision-makers).

The fifth theme revealed that belief in the benefits of the diet in line with the results of the study shows that changing to a healthy diet can rearrange the normal insulin production process and improve the condition of type 2 diabetes (Mann, Allegrante, Natarajan, Halm, \& Charlson, 2007). The excess food intake is reduced significantly through a low-calorie diet. It shows that a decrease in body fat results in the stabilization of insulin sensitivity. T2DM patients only need to lose one-sixth of their body weight to be able to remove fat from the pancreas, thus allowing the organ to produce enough insulin to return to normal levels (Sublett \& Bernstein, 2011).

Other findings from the interview were that the participants expressed some positive feelings towards the diet such as feeling healthy because of self-suggestion, used to being disciplined, being interested in the dietary advice, being satisfied with the present situation, and feeling happy and healthier. DM patients who can change their perspective of suffering will be able to see the meaning and wisdom 
of their illness. The meaning of life can be found in the suffering condition that cannot be avoided (Frankl, 2004). Individuals who have a meaningful life experience show a vibrant lifestyle that is full of enthusiasm and passion for life. They become more directed, more disciplined, and adapt to the environment (Bastaman, 2007).

\section{CONCLUSION}

The findings of this study revealed the motivation, activity, intention and dietary adherence behavior. This includes complying with the amount, types and time of the diet recommendations and reducing their fat and sugar consumption as the themes. If the patient complies with the dietary advice, the easiness of meeting the dietary guidance will increase their dietary adherence too. Easiness can be gained if the participant feels the benefit of the diet or the perceived benefit of the diet. Health workers need to provide health education to every T2DM patient in order to increase the perceived benefits of dietary adherence. A good understanding of the importance of dietary adherence will improve the patients' behavior in complying with the dietary recommendation.

\section{REFERENCES}

ADA. (2017). Panduan Terbaru ADA 2017 Berfokus pada Pendekatan Holistik. Kalbemed, 44(9), 638639.

Ajzen, I. (2005). Attitudes, Personality, and Behavior (2nd ed.). UK: McGraw-Hill.

Bastaman. (2007). Logoterapi: Psikologi untuk Menemukan Makna Hidup dan Meraih Hidup Bermakna. Jakarta: PT RajaGrafindo Persada.

Basu, S., \& Garg, S. (2017). The barriers and challenges toward addressing the social and cultural factors influencing diabetes self-management in Indian populations. Journal of Social Health and Diabetes, 05(02), 071-076. https://doi.org/10.1055/s0038-1676245

Colberg, S. R., Sigal, R. J., Yardley, J. E., Riddell, M. C., Dunstan, D. W., Dempsey, P. C., ... Tate, D. F. (2016). Physical activity/exercise and diabetes: A position statement of the American Diabetes Association. Diabetes Care, 39(11), 2065-2079. https://doi.org/10.2337/dc16-1728

De Souza Ribeiro, M. de N., Diniz, C. X., Perdomo, S. B., De Souza Ribeiro, J. H., Barbosa, O. G., De Barros, K. M. S. C., ... Da Costa Oliveira, E. (2017). Self-esteem and resilience in people with type 2 diabetes mellitus. Mundo Da Saude, 41(2), 223-231. https://doi.org/10.15343/01047809.20174102223231

Delamater, A. M. (2006). Improving Patient Adherence. Clinical Diabetes, 24(2), 71-77. https://doi.org/https://doi.org/10.2337/diaclin. 24.2.71
Doolittle, B. R., \& Farrell, M. (2004). The Association Between Spirituality and Depression in an Urban Clinic. The Primary Care Companion to The Journal of Clinical Psychiatry, 06(03), 114-118. https://doi.org/10.4088/pcc.v06n0302

Fereday, J., \& Muir-Cochrane, E. (2006). Demonstrating Rigor Using Thematic Analysis: A Hybrid Approach of Inductive and Deductive Coding and Theme Development. International Journal of Qualitative Methods, 5(1), 80-92. https://doi.org/10.1177/160940690600500107

Frankl, V. E. (2004). Man's Search for Meaning. Bandung: Yayasan Nuansa Cendikia.

Friedman, P. H. (2018). Life Balance, Emotional Stability, Well-Being and Spiritual Awakening. The International Journal of Healing and Caring, 18(1), 1-21.

Gordan, M., \& Amutan, K. I. (2014). A Review of B. F. Skinner's 'Reinforcement Theory of Motivation. International Journal of Research in Education Methodology, 5(3), 680-688.

Green, L. W., \& Kreuter, M. W. (1991). Health promotion planning: an educational and environmental approach. Mountain View, CA: Mayfield Pub. Co.

Hilliard, M. E., McQuaid, E. L., Nabors, L., \& Hood, K. K. (2014). Resilience in youth and families living with pediatric health and developmental conditions: Introduction to the special issue on resilience. Journal of Pediatric Psychology, 40(9), 835-839.

https://doi.org/10.1093/jpepsy/jsv072

Ilmah, F., \& Rochmah, T. N. (2015). Kepatuhan Pasien Rawat Inap Diet Diabetes Mellitus Berdasarkan Teori Kepatuhan Niven. Jurnal Administrasi Kesehetan Indonesia, 3(1), 60-69. https://doi.org/http://dx.doi.org/10.20473/jaki. v3i1.2015.60-69

Indonesia, I. N. I. of H. R. and D. (2018). Main Resulth of Baseline Health Research 2018. Jakarta: Ministry of Health of the Republic of Indonesia.

L Mccaslin, M., \& Scott, K. W. (2003). The FiveQuestion Method for Framing a Qualitative Research Study. Qual Rep, 8(3), 447-461.

Mann, D. M., Allegrante, J. P., Natarajan, S., Halm, E. A., \& Charlson, M. (2007). Predictors of adherence to statins for primary prevention. Cardiovascular Drugs and Therapy, 21(4), 311-316. https://doi.org/10.1007/s10557-007-6040-4

Moehyi. (1992). Pengaturan Makanan dan Diit Untuk Penyembuhan Penyakit. Cetakan Keempat. Jakarta: PT Gramedia Pustaka Utama.

Niven, N. (2002). Psikologi Kesehatan Keperawatan Pengantar untuk Perawat dan Profesional Kesehatan lain. Jakarta: EGC. 
Notoatmodjo. (2007). Promosi Kesehatan dan Ilmu Perilaku. Jakarta: Rineka Cipta.

Notoatmodjo, S. (2003). Pendidikan dan Perilaku Kesehatan. Jakarta: Rineka Cipta.

PERKENI. (2015). Konsnsus Pengelolaan dan Pencegahan Diabetes Melitus Tipe 2 di Indonesia 2015. Jakarta: Pengurus Besar Perkumpulan Endokrinologi Indonesia.

Pinidiyapathirage, J., Jayasuriya, R., Cheung, N. W., \& Schwarzer, R. (2018). Self-efficacy and planning strategies can improve physical activity levels in women with a recent history of gestational diabetes mellitus. Psychology \& Health, 0446, 1-16. https://doi.org/10.1080/08870446.2018.14589 83

Poretsky, L. (2017). Principles of Diabetes Mellitus. (Springer, Ed.) (3rd ed.). New York.

Restuning, D. (2015). Efektifitas Edukasi Diabetes dalam Meningkatkan Kepatuhan Pengaturan Diet pada Diabetes Melitus Tipe 2. Mutiara Medika, 15(1), 37-41.

Sommer, L. (2011). The Theory Of Planned Behaviour and The Impact Of Past Behaviour. International Business \& Economics Research Journal, 10(1), 91-
110. https://doi.org/10.19030/iber.v10i1.930

Storz, M. A., \& Iraci, F. (2019). Short-term Dietary Oatmeal Interventions in Type 2 Diabetes: A Forgotten Tool. Canadian Journal of Diabetes. https://doi.org/10.1016/j.jcjd.2019.08.020

Sublett, W., \& Bernstein, J. A. (2011). Seminal Plasma Hypersensitivity Reactions: An Updated Review. Mount Sinai Journal of Medicine: A Journal of Translational and Personalized Medicine, 78(5), 803-809.

https://doi.org/doi:10.1002/msj.20283

Van Dam, H. A., Van Der Horst, F. G., Knoops, L., Ryckman, R. M., Crebolder, H. F. J. M., \& Van Den Borne, B. H. W. (2005). Social support in diabetes: A systematic review of controlled intervention studies. Patient Education and Counseling, 59(1), 1-12. https://doi.org/10.1016/j.pec.2004.11.001

Vanwynsberghe, R. (2007). Redefining Case Study Vancouver , Canada. International Journal of Qualitative Methods, 6(2), 80-94.

Wahyuningsih. (2009). Faktor yang Mempengaruhi Sisa Makanan Penderita Diit Diabetes Mellitus di Rumah Sakit Darmo Surabaya. Universitas Airlangga. 